University of Pennsylvania Carey Law School

Penn Carey Law: Legal Scholarship Repository

Faculty Scholarship at Penn Carey Law

2022

\title{
A Miser's Rule of Reason: Student Athlete Compensation and the Alston Antitrust Case
}

Herbert J. Hovenkamp

University of Pennsylvania Carey Law School

Follow this and additional works at: https://scholarship.law.upenn.edu/faculty_scholarship

Part of the Antitrust and Trade Regulation Commons, Courts Commons, Education Law Commons, Industrial Organization Commons, Labor and Employment Law Commons, Labor Economics Commons, Law and Economics Commons, Litigation Commons, and the Supreme Court of the United States Commons

\section{Repository Citation}

Hovenkamp, Herbert J., "A Miser's Rule of Reason: Student Athlete Compensation and the Alston Antitrust Case" (2022). Faculty Scholarship at Penn Carey Law. 2533.

https://scholarship.law.upenn.edu/faculty_scholarship/2533

This Article is brought to you for free and open access by Penn Carey Law: Legal Scholarship Repository. It has been accepted for inclusion in Faculty Scholarship at Penn Carey Law by an authorized administrator of Penn Carey Law: Legal Scholarship Repository. For more information, please contact PennlawIR@law.upenn.edu. 


\title{
A MISER'S RULE OF REASON: THE SUPREME COURT AND ANTITRUST LIMITS ON STUDENT ATHLETE COMPENSATION
}

\author{
HERBERT HOVENKAMP*
}

I.

\section{INTRODUCTION}

The Supreme Court's decision in NCAA v. Alston is one of the most important antitrust rule of reason cases in history-significant both for what it does and what it does not do. ${ }^{1}$ Notably, it is a truly rare decision that private antitrust plaintiffs proceeding under the rule of reason have won. At the same time, it indicates just how narrow the rule of reason path to victory has become. In effect, plaintiffs can win, but perhaps only when they are challenging a cartel or something close. As a result, the decision does little to change the view that the rule of reason, as the courts currently apply it, is a powerful anti-enforcement tool. In its current form, it remains one of the most important roadblocks to antitrust reform.

This article briefly examines Alston, against the backdrop of the large number of antitrust cases that have been brought against the NCAA, and also queries whether the decision moves the strongly tilted anti-enforcement rule of reason in a positive direction. It also considers how we got to this point, where about the only time that plaintiffs can win a rule of reason case is when they are suing what is in fact a naked cartel, although one with some complicating features.

The Supreme Court unanimously agreed with the lower courts that certain restrictions that the NCAA imposed on member schools limiting compensation to student athletes violated $\S 1$ of the Sherman Act. ${ }^{2}$

The plaintiffs were football and basketball players subjected to these limitations. The lower courts had struck down specific NCAA rules that limited collateral, education-related benefits that student

* James G. Dinan University Professor, University of Pennsylvania Carey Law School and the Wharton School.

1. Nat'l Collegiate Athletic Ass'n v. Alston, 141 S. Ct. 2141 (2021).

2. Id. Justice Gorsuch delivered the opinion, which was unanimous. Justice Kavanaugh wrote a brief concurring opinion. 
athletes could receive, including graduate or vocational school scholarships. ${ }^{3}$ They declined to condemn regulations that the NCAA, an organization of 1,100 member schools, applied to direct scholarships and other aid related to athletic performance. ${ }^{4}$ Nor did they pass judgment on any issue regarding player compensation more generally, such as whether NCAA member schools could individually pay students any salary they wished. Finally, the decision did not raise issues about the numerous restrictive rules that the NCAA imposes that do not involve athlete compensation, nor about the question of compensation for NCAA coaches or other staff members.

The NCAA had argued that the district court overreached by weakening its restraints on education-related athlete compensation. ${ }^{5}$ The student athletes, by contrast, said that the court should have enjoined all of the challenged compensation limits, including those not related to education, as well as restrictions on the size of athletic scholarships and cash awards. ${ }^{6}$ The district court agreed with the student plaintiffs tat the restrictions imposed "significant anticompetitive effects" by permitting the NCAA to use its monopsony power to "cap artificially the compensation offered to recruits." 7 It found that in the absence of these restrictions, compensation would have been higher. ${ }^{8}$

To examine the legality of the relevant practices, the court applied the antitrust test known as the rule of reason. Under the rule of reason, once a plaintiff has made out a prima facie case showing anticompetitive effects, the burden of proof shifts to the defendants to show a justification. If the defendants succeed, the plaintiff can still prevail by showing that the same justification could have been achieved through a less restrictive alternative. ${ }^{9}$

The district court also rejected many of the NCAA's proffered justifications. One of them, that the restrictions increased output in the product market, was not pursued to the Supreme Court. ${ }^{10}$ Another was that the rules were designed to preserve amateurism in

3. In re Nat'l Collegiate Athletic Ass'n Athletic Grant-in-Aid Cap Antitrust Litig., 375 F. Supp. 3d 1058 (N.D. Cal. 2019), aff'd, 958 F.3d 1239 (9th Cir. 2020).

4. $I d$. at 1109 .

5. Brief for Petitioners at 14-15, Nat'l Collegiate Athletic Ass'n v. Alston, 141

S. Ct. 2141 (2021) (No. 20-520).

6. Alston, 141 S. Ct. at 2154.

7. Id. at 2152 (quoting the district court, 375 F. Supp. 3d at 1097).

8. $I d$.

9. See 7 Phillip E. Areeda \& Herbert Hovenkamp, Antitrust law If 1505 (4th ed. 2017).

10. Alston, 141 S. Ct. at 2152. 
collegiate sports, and that this was a benefit that accrued to consumers rather than to the student athletes themselves. ${ }^{11}$ The district court had responded that the concept of amateurism was never very well defined. ${ }^{12}$ Further, the link between amateurism and consumer demand was never established. ${ }^{13}$ It did suggest, however, that a rule against unlimited compensation might have operated to distinguish collegiate from professional athletics and thus "help sustain consumer demand for college athletics." 14

Under the third step of rule of reason analysis, the students also attempted to show less restrictive alternatives to those rules for which the court had found justifications, and the court concluded that they had partially done so. The less restrictive alternative was to permit a cap on compensation, provided that it was not less than the full cost of attendance. ${ }^{15}$ It declined to enjoin the rules limiting compensation to the full cost of an education and those that restricted benefits unrelated to their education. However, it found that the caps limiting scholarships for graduate or vocational school, payments for academic tutoring, or post-eligibility internships were unlawful because these could not be confused with the compensation given to professional athletes. ${ }^{16}$ As the Supreme Court subsequently observed:

Nothing in the [lower court's] order precluded the NCAA from continuing to fix compensation and benefits unrelated to education; limits on athletic scholarships, for example, remained untouched. The court enjoined the NCAA only from limiting education-related compensation or benefits that conferences and schools may provide to student-athletes playing Division I football and basketball. The court's injunction further specified that the NCAA could continue to limit cash awards for academic achievement-but only so long as those limits are no lower than the cash awards allowed for athletic achievement (currently $\$ 5,980$ annually). ${ }^{17}$

The Ninth Circuit affirmed the entire decree. ${ }^{18}$ The NCAA, but not the students, petitioned the Supreme Court with respect to

11. $I d$.

12. Id.

13. Id. at $2152-53$.

14. Id. at 2153 (citing the district court, 375 F. Supp. 3d 1058, 1083 (N.D. Cal. 2019)).

15. Id.; see discussion infra notes 97-106.

16. Alston, 141 S. Ct. at 2153.

17. Id.

18. Id. at 2154 . 
those parts of the decree that were averse to it. As a result, the Court's decision addressed only the NCAA's disputes with the lower courts. With respect to those, the Supreme Court affirmed the district court's decree in all respects.

The Supreme Court posed the question as whether the NCAA was seeking "immunity from the normal operation of the antitrust laws . . . ."19 It opened with a colorful history of intercollegiate sports, including the highly disorganized and indefensible mechanisms that the schools used to recruit athletes and compensate them for play. ${ }^{20}$ These included such things as the temporary hiring of ringers to play for a single game and side payments to prominent athletes from wealthy fans. ${ }^{21}$ Much of the debate prior to this decision involved the student athletes' status as "amateurs" and the various rules intended to permit schools to compensate athletes for the cost of tuition, room and board, and some other elements of school attendance, but not more. Over the years these rules had evolved, permitting some additional compensation, but always significantly limited to below market levels, at least for superstar athletes. The Court also observed that intercollegiate sports, particularly football and basketball, had evolved into multibillion dollar enterprises, paying very high salaries to principal employees such as athletic directors and head coaches. ${ }^{22}$

The Supreme Court noted that the district court had been compelled to apply the rule of reason, as the Supreme Court's own 1984 Oklahoma Board of Regents decision had instructed.23 On the question of market power, it then concluded that the NCAA enjoys "near complete dominance" and "monopsony power" in a relevant market defined as "athletic services in men's and women's Division I basketball and FBS [(Football Bowl Subdivision)] football." 24 This was essentially "the relevant market for elite college football and basketball."25

The Supreme Court observed that neither side challenged the district court's market definition or the proposition that the NCAA enjoys monopsony power in the labor market in question. Nor did

19. Id. at 2159 .

20. Id. at $2148-51$.

21. Id.

22. $I d$.

23. Nat'l Collegiate Athletic Ass'n v. Bd. of Regents of Univ. of Okla., 468 U.S. 85, 104 (1984).

24. Alston, 141 S. Ct. at 2151-52 (citing the district court, 375 F. Supp. 3d 1058, 1097 (N.D. Cal. 2019)).

25. Id. at 2152 (citing the district court, 375 F. Supp. 3d at 1067). 
the NCAA dispute the fact of price fixing, or that the restrictions operated so as to decrease student compensation in fact. ${ }^{26}$ Nor did they dispute that these limitations tended to depress both the quantity and quality of participation by student athletes. ${ }^{27}$ As a result, the soundness of the plaintiffs' prima facie case was largely assumed.

\section{A. The Exercise of Monopsony Power}

The Court also held that suppression of competition on the buying (student athlete) side of the relevant market was all the competitive harm that was necessary; that is, the plaintiffs did not additionally need to show harm to the selling side of the market. ${ }^{28}$ The importance of this distinction is that cognizable monopsony harm to the buy-side of the market alone is sufficient. It is not merely derivative of harm on the selling, or monopoly, side of the market. This has always been clear in the economic theory of monopsony, ${ }^{29}$ and most have thought that it was clear in antitrust law as well. ${ }^{30}$

If a cartel or firm has market power on both the buying side and the selling side of its market, then harm to both sides is likely. The purchasing cartel forces a reduced purchase price by reducing the quantity it purchases, which would usually show up as reduced output on the sell-side as well. If the sell-side controlled some market power, the result would be competitive harm on both the buying and selling side of the market. If the selling side was competitive, however, then the result would be competitive harm on the buying side but not on the selling side. Assuming that the NCAA wielded power in both the market where it purchased athletic services and the markets where it sold game tickets and adver-

26. Id. at $2154-55$.

27. $I d$. at 2154 (citing 12 Phillip E. Areeda \& Herbert Hovenkamp, AntiTRUST LAW II 2011b (4th ed. 2019)).

28. Id. (first citing 2A Phillip E. Areeda \& Herbert Hovenkamp, Antitrust Law II 352c (2014); and then citing 12 Phillip E. Areeda \& Herbert Hovenkamp, Antitrust LaW II 2011a).

29. See, e.g., Roger D. Blair \& Jeffrey L. Harrison, Antitrust Policy and Monopsony, 76 Cornell L. Rev. 297 (1991); Roger D. Blair \& JefFrey L. Harrison, MoNOPSONY in LAw And Economics (Cambridge Univ. Press, 2d ed. 2010). On the relationship between market power and output on the two sides, see Herbert Hovenkamp, Worker Welfare and Antitrust, Univ. Chi. L. Rev. (2022) (forthcoming), https://papers.ssrn.com/sol3/papers.cfm?abstract_id=4015834 [https:// perma.cc/5S3N-F9ZE].

30. See, e.g., 2B Phillip E. Areeda \& Herbert Hovenkamp, Antitrust Law I 575 (5th ed. 2020); 4A id. II 980-82 (4th ed. 2016). 
tising, the athlete-buying cartel very likely did result in a restraint on the sell-side as well, but the Court did not require that showing.

The idea that harm to the buy-side of the market is independently challengeable under the antitrust laws makes it unnecessary to prove competitive harm on the selling side of the market. The Supreme Court had already established this in Mandeville Island Farms v. American Crystal Sugar Co. ${ }^{31}$ It approved a price-fixing complaint in the market for sugar beets, which was local because sugar beets could be shipped only a short distance to a refiner. However, the beets were processed into sugar that was sold in a much more competitive national market, and also in competition with cane sugar. ${ }^{32}$ Both the district court and the Ninth Circuit had dismissed the complaint for failure to show any effect on the market for refined sugar. ${ }^{33}$ The Supreme Court reversed, concluding that a showing of harm to the national refined sugar market was unnecessary, provided that the restraint occurred in the local purchasing market. ${ }^{34}$ Justices Jackson and Frankfurter dissented on that point. ${ }^{35}$

Because $\S 2$ of the Sherman Act $^{36}$ does not reference either buyers or sellers, it also applies equally to buy-side monopoly. Section 7 of the Clayton Act ${ }^{37}$ is similar, applying equally to both sellside and buy-side anticompetitive effects from mergers. ${ }^{38}$ By contrast, $\S 3$ of the Clayton Act, which covers exclusive dealing and tying, explicitly covers only sellers. ${ }^{39}$

The question of offsetting benefits on the selling side of the market is analytically distinctive from the question of harm on both sides. The student athletes did not dispute that it would be permissible for the NCAA to justify labor market restraints by pointing to offsetting benefits on the consumer side of the market. The Court

31. 334 U.S. 219 (1948). The Supreme Court cited Mandeville for this proposition. See Alston, 141 S. Ct. at 2154.

32. See Philip Marcus, Antitrust Bugbears: Substitute Products - Oligopoly, 105 U. PA. L. Rev. 185 (1956).

33. See Mandeville Island Farms v. Am. Crystal Sugar Co., 64 F. Supp. 265, 268 (S.D. Cal. 1946); Mandeville Island Farms, Inc. v. Am. Crystal Sugar Co., 159 F.2d 71, 71-72 (9th Cir. 1947).

34. Mandeville Island Farms, 334 U.S. at 228-29.

35. Id. at 247 (Jackson, J., dissenting).

36. 15 U.S.C.A. $\$ 2$ (2004).

37. 15 U.S.C.A. $\$ 18$ (1996).

38. On mergers with anticompetitive effects in purchasing markets, see $4 \mathrm{~A}$ Phillip E. Areeda \& Herbert Hovenkamp, Antitrust Law II fl 980-82 (4th ed. 2017).

39. 15 U.S.C.A. $§ 14$ ("It shall be unlawful . . to lease or make a sale . ..."). 
noted that some amici had argued that such "out of market" offsets would not be permissible, but the parties themselves did not pursue it and neither did the Court. ${ }^{40}$

The offsetting benefits question is complex and depends on the rationale for the buy-side price reduction. As noted above, when a buying cartel suppresses compensation by limiting its purchases, the result typically harms the sell-side as well because output goes down. ${ }^{41}$ By contrast, when a buyer is able to achieve lower costs through more efficient procurement, the result is typically higher output on the buying side and typically on the selling side as well. For example, if a manufacturer adopts more automated technology that enables it to hire fewer or less-skilled workers, the result would be lower aggregate wages. Mergers or other consolidations that limit unnecessary duplication can do the same thing. These would not result from a buy-side output reduction, however, but rather from reduced production costs that would ordinarily lead to higher output on the selling side.

\section{B. The Rule of Reason in Antitrust Challenges to the NCAA}

In the 1984 Oklahoma Board of Regents decision, the Supreme Court concluded that the rule of reason should apply to restraints established by agreement among NCAA members because cooperation among teams was necessary in order to create the product in question at all. ${ }^{42}$ The NCAA in the present case argued that this legal rule supported its argument that there should be truncated deferential review favoring the restrictions in this case. ${ }^{43}$ The Court dismissed that argument, but it also did not conclude that this was either a per se unlawful or a per se lawful restraint. While some restraints could be evaluated "in the 'twinkling of an eye," "44 that was true only for "restraints at opposite ends of the competitive spectrum," not for those in the "great in-between." 45 Among the former would be restraints in which market power was clearly lack-

40. Nat'l Collegiate Athletic Ass'n v. Alston, 141 S. Ct. 2141, 2155 (2021) ("[W]e express no views on [these matters.]").

41. See Hovenkamp, Worker Welfare and Antitrust, supra note 29 (noting that labor is a variable cost and thus its output is suppressed when output in the product market is suppressed).

42. Nat'l Collegiate Athletic Ass'n v. Bd. of Regents of Univ. of Okla., 468 U.S. 85, 101 (1984) (Some "horizontal restraints on competition are essential if the product is to be available at all.").

43. Alston, 141 S. Ct. at 2155.

44. Id. (quoting Phillip Areeda, The "Rule of Reason" in Antitrust Analysis: General Issues 37-38 (Fed. Jud. Ctr., June 1981)).

45. Id. 
ing. ${ }^{46}$ In this case, however, the NCAA did not dispute the fact of its market power. ${ }^{47}$ As a result, the Court concluded that a "quick look" was not appropriate. ${ }^{48}$

Then, getting to the rule of reason itself, the Court noted its own previous references to a "three-step, burden-shifting framework" for identifying anticompetitive restraints. ${ }^{49}$ However, these three steps "do not present a rote checklist," but must be used flexibly, providing a rule that is "meet for the case, looking to the circumstances, details, and logic of a restraint." 50 Here, the district court had required "the student-athletes to show that 'the challenged restraints produce significant anticompetitive effects in the relevant market." 51 The Court noted that this was "no slight burden" and that "courts have disposed of nearly all rule of reason cases in the last 45 years on that ground." 52 But this case was different:

. . . based on a voluminous record, the district court held that the student-athletes had shown the NCAA enjoys the power to set wages in the market for student-athletes' labor-and that the NCAA has exercised that power in ways that have produced significant anticompetitive effects. Perhaps even more notably, the NCAA "did not meaningfully dispute" this conclusion. ${ }^{53}$

The second step the district court followed was to determine whether "the NCAA could muster a procompetitive rationale for its restraints." 54 Here, the NCAA claimed error in that the district court looked at the restraints collectively in order to determine competitive harm, but individually in order to assess offsetting benefits. This "mismatch," the defendants argued, required the defendant to prove that each individual rule that was challenged was "the

46. Id. at 2156 (first citing Rothery Storage \& Van Co. v. Atlas Van Lines, Inc., 792 F.2d 210, 217 (D.C. Cir. 1986); and then citing 7 Phillip E. Areeda \& Herbert Hovenkamp, Antitrust Law If 1507a (4th ed. 2017)).

47. Alston, 141 S. Ct. at 2156-57.

48. On the "quick look," see discussion infra notes 103-13.

49. Alston, 141 S. Ct. at 2160 (quoting Ohio v. Am. Express Co., 138 S. Ct. $2274,2284(2018))$.

50. Id. (first citing Cal. Dental Ass'n v. FTC, 526 U.S. 756, 781 (1999); and then citing 7 Phillip E. Areeda \& Herbert Hovenkamp, Antitrust Law If 1507a (4th ed. 2017), which it described as offering a "slightly different 'decisional model' using sequential questions"). 2019)).

51. Id. (quoting the district court, 375 F. Supp. 3d 1058, 1067 (N.D. Cal.

52. Id. at 2161. On the importance of this, see discussion infra note 77. 1067).

53. Alston, 141 S. Ct. at 2161 (quoting the district court, 375 F. Supp. 3d at

54. Id. (citing the district court, 375 F. Supp. 3d at 1070). 
least restrictive means of achieving the procompetitive purpose of differentiating college sports and preserving demand for them." 55

Here, the Court agreed with the NCAA's premise "that antitrust law does not require businesses to use anything like the least restrictive means of achieving legitimate business purposes." 56 The Court should not be second guessing "degrees of reasonable necessity" because "skilled lawyers" will "have little difficulty imagining possible less restrictive alternatives to most joint arrangements." 57 It later warned that courts should give "wide berth to business judgments before finding liability." 58 The Court also cautioned against rules that attempt to micro-manage the details of business judgments. Along these lines, the Court stated that " $[\mathrm{t}]$ o know that the Sherman Act prohibits only unreasonable restraints of trade is thus to know that attempts to "meter" small deviations is not an appropriate antitrust function." "59

The Court agreed with the district court that the NCAA's proffered defenses failed to "have any direct connection to consumer demand." 60 The Court then qualified:

To be sure, there is a wrinkle here. While finding the NCAA had failed to establish that its rules collectively sustain consumer demand, the court did find that "some" of those rules "may" have procompetitive effects "to the extent" they prohibit compensation "unrelated to education, akin to salaries seen in professional sports leagues." The court then proceeded to what corresponds to the third step of the American Express framework, where it required the student-athletes "to show that there are substantially less restrictive alternative rules that would achieve the same procompetitive effect as the challenged set of rules." And there, of course, the district court held that the student-athletes partially succeeded-they were able to show that the NCAA could achieve the procompetitive benefits it had established with substantially less restrictive restraints on education-related benefits. ${ }^{61}$

55. Id. at 2161.

56. $I d$.

57. Id. (citing 11 Phillip E. Areeda \& Herbert Hovenkamp, Antitrust Law I 1913b (2018); and for a slightly different proposition, 7 Phillip E. Areeda \& HerBert Hovenkamp, ANTitrust Law I 1505b).

58. Id. at 2163.

59. Id. at 2161 (quoting Herbert Hovenkamp, Antitrust Balancing, 12 N.Y.U. L. \& Bus. 369, 377 (2016)).

60. Id. at 2162 (quoting the district court, 375 F. Supp. 3d 1058, 1070 (N.D. Cal. 2019)).

61. Id. (quoting the district court, 375 F. Supp. $3 \mathrm{~d}$ at 1082-83, 1104). 
It continued:

Of course, deficiencies in the NCAA's proof of procompetitive benefits at the second step influenced the analysis at the third. But that is only because, however framed and at whichever step, anticompetitive restraints of trade may wind up flunking the rule of reason to the extent the evidence shows that substantially less restrictive means exist to achieve any proven procompetitive benefits .... "To be sure, these two questions can be collapsed into one," since a "legitimate objective that is not promoted by the challenged restraint can be equally served by simply abandoning the restraint, which is surely a less restrictive alternative". ${ }^{62}$

Effectively, this meant that the district court had correctly found, not that the rules were the least restrictive means of preserving consumer demand, but rather that the restraints were "patently and inexplicably stricter than is necessary" to achieve the declared procompetitive benefits. ${ }^{63}$

II.

\section{THE RULE OF REASON: ONE STEP OR THREE?}

In its 1984 Oklahoma Board of Regents decision, the Supreme Court held that the rule of reason should be applied to a joint venture if the product could not be produced at all without collaborative activity. ${ }^{64}$ The Alston Court did not overrule that formulation, and the rule of reason has become all but automatic in all antitrust cases against the NCAA, as well as other sports leagues and many other joint ventures that involve collaborative product development. At one point, the Court noted, however, that the fact that "some restraints are necessary to create or maintain a league sport" does not mean all "aspects of elaborate interleague cooperation are." 65

The Court's 1984 conclusion about the scope of the rule of reason was stated more broadly than it needed to be to address the case at hand. The result has been to make economic evaluation of

62. Id. (quoting 7 Phillip E. Areeda \& Herbert Hovenkamp, Antitrust LaW If 1505 (4th ed. 2017)).

63. Id. (quoting the district court, 375 F. Supp. $3 \mathrm{~d}$ at 1104).

64. Nat'l Collegiate Athletic Ass'n v. Bd. of Regents of Univ. of Okla., 468 U.S. 85, 101 (1984) (Some "horizontal restraints on competition are essential if the product is to be available at all.").

65. Alston, 141 S. Ct. at 2156 (quoting Am. Needle, Inc. v. Nat'l Football League, 560 U.S. 183, 199 n.7 (2010)). 
practices in joint ventures excessively cumbersome and costly-a result that reaches far beyond the NCAA sports cases. ${ }^{66}$

Some practices within the NCAA need to be coordinated in order to make the product available, while others do not. For example, suppose the NCAA promulgated a rule fixing the price of hot dogs sold in stadiums hosting NCAA events. Is there any reason to subject that practice to all of the cost that accompanies rule of reason treatment, including an assessment of market power, simply because other practices that do require cooperation must be treated more deferentially? The rule of reason is a costly tool. It is worth its price only if its use produces sufficiently greater accuracy.

The well-established antitrust distinction between "naked" and "ancillary" restraints would actually work quite well for this purpose. An ancillary restraint is one that is reasonably necessary for the functioning of the venture and achievement of its purpose. ${ }^{67}$ Further, its profitability does not depend on the exercise of market power. To be sure, the NCAA presents some unusual complexities because of its nonprofit status and its role in the education process as well as its responsibility in loco parentis for student growth and discipline. But these are largely addressed "jurisdictionally," by considering whether the challenged restraint is commercial in character and thus within the Sherman Act's limitations to commerce. ${ }^{68}$

The Alston Court also observed that prior courts had adopted a three-step burden-shifting framework for analyzing restraints under the rule of reason. ${ }^{69}$ This decision-making approach is a significant improvement over Justice Brandeis' original statement of the rule of reason in the Chicago Board of Trade case. ${ }^{70}$ Looking at an agreement that both restrained prices and promised to make a market perform better, Justice Brandeis queried whether the restraint

66. See, e.g., In re ATM Fee Antitrust Litig., 554 F. Supp. 2d 1003, 1014 (N.D. Cal. 2008) (network coordination); Martin v. Am. Kennel Club, Inc., 697 F. Supp. 997, 1001 (N.D. Ill. 1988) (collaborative rules for dog shows); see also Nw. Wholesale Stationers, Inc. v. Pac. Stationery \& Printing, Co., 472 U.S. 284, 295 (1985) (citing this language in concluding that the activities of a cooperative buying association should be addressed under the rule of reason); $c f$. United States v. Apple, Inc., 791 F.3d 290, 326 (2d Cir. 2015) (finding that the language did not apply to a naked boycott agreement); Dagher v. Saudi Ref., Inc., 369 F.3d 1108, 1122 (9th Cir. 2004) (did not apply to a production joint venture), rev'd, 547 U.S. 1 (2006).

67. See Texaco Inc. v. Dagher, 547 U.S. 1, 7-8 (2006).

68. See 1B Phillip E. Areeda \& Herbert Hovenkamp, Antitrust Law Il 260 (5th ed. 2020) (commercial activities generally); $i d$. II 261 (nonprofit organizations); id. II 262 (noncommercial activities); see discussion infra notes 132-40.

69. Alston, 141 S. Ct. at 2151 (citing Ohio v. Am. Express Co., 138 S. Ct. 2274, $2284(2018))$.

70. Bd. of Trade of Chicago v. United States, 246 U.S. 231, 238 (1918). 
"merely regulated and perhaps thereby promotes competition," or whether it might "suppress or even destroy competition." 11 To answer that question, he concluded that the court would have to consider the history of the business and the restraint, the condition of the market before and after the restraint was imposed, and its "effect, actual or probable." 72 In other words, the parties were invited to throw in everything relevant to the business and see what sticks. That formulation led to a rule of reason jurisprudence that required enormous records and trials. ${ }^{73}$

Today's rule of reason takes an approach that is both more focused and more transactional, insisting on market power and the identification of practices that threaten to reduce market output and raise price. ${ }^{74}$ The burden-shifting framework is designed to guide this query, placing the burden of proof where it is calculated to produce results efficiently in the majority of cases. The prima facie case must initially be made by the plaintiff, who should be able to plead and prove a theory of competitive harm and, if necessary, injury. By contrast, because the defendant is the author of the conduct, it should be in the best position to understand its motives and perceived effects. Under this framework, the plaintiff has an initial burden of making a prima facie case showing that the challenged restraint has a "substantial anticompetitive effect." 75 At that point, the burden shifts to the defendant to prove a procompetitive rationale. If the defendant shows one, then the burden shifts back to the plaintiff for an opportunity to show that the procompetitive rationale could be achieved by less anticompetitive means. ${ }^{76}$

In Alston, the Supreme Court observed, however, that plaintiffs rarely get past the first step. In fact, $90 \%$ of cases litigated in the previous 45 years were dismissed because the plaintiff failed at the first stage. ${ }^{77}$ The Court found the present case to be one of the

71. Id.

72. $I d$.

73. See Herbert Hovenkamp, Federal Antitrust Policy: The Law of Competition And Its Practice $\$ 5.6$ (6th ed. 2020).

74. See 7 Phillip E. Areeda \& Herbert Hovenkamp, Antitrust Law, Ch. 15 (4th ed. 2017).

75. Nat'l Collegiate Athletic Ass'n v. Alston, 141 S. Ct. 2141, 2160 (2021).

76. Id. (citing 7 Phillip E. Areeda \& Herbert Hovenkamp, Antitrust Law If 1507a (4th ed. 2017)).

77. Id. at 2160-61 (citing Brief for 65 Professors of Law, Business, Economics, and Sports Management as Amici Curiae at 21 n.9, Alston, 141 S. Ct. 2141 (2021) (Nos. 20-512, 20-520)). For the empirical work supporting this proposition, see Michael A. Carrier, The Real Rule of Reason: Bridging the Disconnect, 1999 BYU L. REv. 1265, 1268 (1999); Michael A. Carrier, The Rule of Reason: An Empirical Update for the 
exceptions. ${ }^{78}$ And, of course, it should have been, given that the challenge was to what amounted to a naked cartel.

The Court did not seek to determine why plaintiffs' cases fail so frequently at the first, or prima facie, stage. One possibility, of course, is that plaintiffs bring a lot of weak cases. Another one, however, is that the plaintiff's burden created by the courts for the first stage is unreasonably harsh. If that is the case, then some harmful restraints escape because of judicial, rather than plaintiff, error.

A likely explanation for this is exaggerated judicial confidence that markets will usually correct anticompetitive practices, and more quickly than the courts can do it. Today, a wealth of empirical observation and literature shows that this premise is both theoretically and empirically incorrect, but it has had surprising durability in antitrust policy. ${ }^{79}$ It shows up powerfully in federal court tendencies to articulate a three-part rule of reason, but then to load all of the important requirements into the first part-effectively, a onepart rule of reason. That increases the plaintiff's burden while minimizing the defendant's need to justify its restraint.

This bias shows up mainly in the ways that the courts address the first stated step. As this Court described it, the plaintiff must show that "the challenged restraint has a substantial anticompetitive effect." 80 Does that mean substantial anticompetitive effect after all efficiencies are netted out? If it does, then the requirement effectively wipes out the second step of the rule of reason because it rolls harms and offsetting efficiencies all into the first step, assigning the burden for both to the plaintiff.

The merger statute, $\S 7$ of the Clayton Act, uses roughly analogous language for assessing mergers- "where . . . the effect . . . may be substantially to lessen competition . . . ." 81 The statute does not contain an efficiency defense, and there has always been some dispute about how efficiencies should be considered. ${ }^{82}$ But the current formulation of merger policy expressed in the Merger Guidelines is that the government makes out a prima facie case

21st Century, 16 Geo. Mason L. Rev. 827 (2009); Michael A. Carrier, The Four-Step Rule of Reason, 33 AntrTRust 50 (Spring 2019).

78. Alston, 141 S. Ct. at 2161.

79. See Herbert Hovenkamp, Antitrust Error Costs, U. PA. J. Bus. L. (forthcoming 2022), https://papers.ssrn.com/sol3/papers.cfm?abstract_id=3853282 [https:/ /perma.cc/G5UU-T94F].

80. Alston, 141 S. Ct. at 2160 (quoting Ohio v. Am. Express Co., 138 S. Ct. 2274, 2284 (2018)).

81. 15 U.S.C.A. $§ 18$ (1996).

82. See 7 Phillip E. Areeda \& Herbert Hovenkamp, Antitrust Law II I 970-73 (4th ed. 2017). 
based largely on structural evidence, and then the burden shifts to the defendant to establish offsetting efficiencies. ${ }^{83}$

Most rule of reason cases do not involve naked or nearly naked cartels. They are concerned with production or research joint ventures, vertical restraints, professional association rules, standard setting, or other types of agreements whose effects are more ambiguous. Alston was the unique rule of reason case in which the practice that the Court was confronting was in fact very close to a naked cartel. The NCAA did very little to undermine that view in its defense. In any other setting, it would have been governed by the per se rule but for an idiosyncratic history that compelled the rule of reason.

Further, the Court often incorporates an anti-enforcement bias that prevents it from seeing competitive harm even when it is right in front of them. A good example is the American Express case, where the Court held that the plaintiff had not met its initial burden. ${ }^{84}$ While the American Express card offered greater perquisites-such as cash back, extended warranties, and travel milesthan competing cards, it also charged significantly higher fees to merchants. The merchants were, in effect, paying for benefits that accrued to the card user. The challenged anti-steering rule forbade merchants from informing customers that card fees for use of an American Express card were significantly higher than those for use of a competing card such as Visa or MasterCard. It also forbade them from offering customers a discount for switching to a different card. ${ }^{85}$

Had the Court applied a more focused, transaction-specific analysis to these rules, it would not have had the trouble that it did in seeing competitive harm. Suppose that the merchant fee for using an American Express card on a large purchase was $\$ 15$, while the fee for accepting a Visa card was $\$ 10$. That difference created $\$ 5$ worth of bargaining room. In that case, the merchant might have offered the customer a $\$ 3$ discount for using a different card. That bargain, had it occurred, would have benefitted the customer by $\$ 3$ less foregone AmEx perquisites. It would have benefitted the merchant by $\$ 2$. The customer would accept the offer only if she valued the discount by more than the foregone perquisites, so the deal would have been a Pareto improvement looking at the two bar-

83. See id. Il $970 f$.

84. Am. Express Co., 138 S. Ct. at 2287.

85. See Erik Hovenkamp, Platform Antitrust, 44 J. Corp. L. 713, 728 (2019). 
gaining parties. ${ }^{86}$ It would permit substitution to the Visa card precisely in those circumstances where use of the Visa card was efficient.

What the Court did not see is that every single instance in which the no-steering rule prevented such a transaction actually caused harm on both sides of the market-i.e., to both the affected customer and the affected merchant. No sensible enforcement-neutral approach to antitrust would have dropped the inquiry. Indeed, the Alston Court expressly characterized the challenged harms resulting from NCAA compensation limitations in terms of price and output. $^{87}$ Rather, the American Express Court should have held that once the plaintiffs showed that the anti-steering rule caused competitive harm on both sides of affected transactions, the burden shifted to American Express to provide a procompetitive justification for its rule. By combining the analysis of anti-competitive effects and pro-competitive effects into one "step" of analysis, the Court set too high of a bar for the plaintiffs.

The Court also did a version of this in the California Dental case, where it concluded that a dental association's restrictions on advertising that prohibited quality advertising and effectively prohibited most forms of price advertising were not sufficiently threatening to require the defendant to provide an explanation. ${ }^{88}$ Once again, it is possible that upon further investigation we might discover that the potential for abuse is so severe that the rules were justified under the circumstances, but the Court effectively cut that inquiry short. 89

If the only time that plaintiffs can successfully proceed through the "three-step" rule of reason case is when the challenged restraint amounts to little more than naked collusion, then the rule of reason is not doing its job and is not really a three-step rule of reason at all. In most rule of reason challenges, including those brought by the government, the plaintiff's prima facie case depends on market evidence that supports reasonable inferences of competitive harm. By contrast, when the burden shifts, the defense typically depends on evidence that pertains to the defendant's own conduct and the rationales for it.

86. See Herbert Hovenkamp, The Looming Crisis in Antitrust Economics, 101 B.U.

L. REv. 489, 514 (2021).

87. Nat'l Collegiate Athletic Ass'n v. Alston, 141 S. Ct. 2141, 2158 (2021).

88. Cal. Dental Ass'n v. FTC, 526 U.S. 756, 758 (1999). (2018).

89. See Herbert Hovenkamp, The Rule of Reason, 70 FLA. L. REv. 81, 98-114 
As a matter of decisional quality, cases that raise significant issues of efficiency or other competitively benign explanations will be more accurately resolved at the second stage, where the defendant has the burden, rather than at the first stage. This does not mean that trivial claims or claims against firms that clearly lack power should go forward. It does suggest, however, that at the first stage, the plaintiff should bear a smaller burden. It should be regarded somewhat more like the probable cause requirements that judges and magistrates use in issuing a search warrant: it should raise reasonable suspicions warranting a further inquiry.

For example, in American Express, the plaintiff had established that each instance of enforcement of the anti-steering rule caused exclusion of a rival credit card that injured both the affected merchant and the affected card holder. ${ }^{90}$ Each time the rule applied, the merchant was denied a less costly card and that customer was denied a discount or other perk that may have been offered in exchange. The only benefit was to American Express itself, which was able to retain a sale that it would have lost in a more competitive setting. At that point, the burden should have shifted to American Express to show that the challenged steering rule (not its overall business model) served a procompetitive purpose and was not simply a way for it to get merchants and users of non-AmEx cards to subsidize its business by denying them the right to bargain for a cheaper payment mechanism. In fact, American Express should have been an easy case, given that each instance of enforcement of the anti-steering rule resulted in harm to both sides of the affected transaction. ${ }^{91}$

While harm to competition entails higher prices and reduced output, most cases do not require actual empirical evidence of such effects. In the Alston case itself, the Court acknowledged that it was easy, mainly because the NCAA never disputed that the "restrictions in fact decrease the compensation that student athletes receive compared to what a competitive market would yield."92 Further, no one questioned that these decreases in compensation also "depress[ed] participation by student-athletes." 93 As a result, both price and output were depressed. ${ }^{94}$

90. Ohio v. Am. Express Co., 138 S. Ct. 2274 (2018).

91. See discussion supra note 71.

92. Alston, 141 S. Ct. at 2154.

93. Id.

94. Id. (citing 12 Phillip E. Areeda \& Herbert Hovenkamp, Antitrust Law I $2011 b$ (4th ed. 2019)). 
In most cases, the proof consists in reasonable inferences that can be drawn from the practices plus our own knowledge of rational behavior under the circumstances. For example, because an AmEx card holder and a merchant in the previous illustrations would agree to a discount for use of a different card, we can infer that, as between the two of them, prices are lower and output higher as a result of the deal. This is not because we have taken an actual empirical measurement of increased output or lower prices, but because parties never make voluntary agreements unless they expect to benefit. As a result, the conclusion that the no-steering rule tended to raise prices and reduce output is sufficient, certainly for a prima facie case.

In a case such as FTC v. Actavis, Inc., which involved a pay-fordelay patent settlement in pharmaceuticals, the inference of harm is strong as well. ${ }^{95}$ The effect of the pay-for-delay patent settlement is to enable the patentee to retain its exclusive right for the duration of the settlement agreement. Prices are significantly higher than they would be in the absence of the settlement agreement. Otherwise, the payment for delay would not be worth it. That still leaves the question whether the agreement is justified because the patent could be valid, but that question is generally determinable by looking at the size of the payment. A person who owns good title to a property interest will typically not be willing to pay hundreds of millions of dollars to exclude trespassers. So a high payment is a strong signal that the parties' expectations are that the patent is invalid. ${ }^{96}$

The Alston Court did not expressly refer to causation, although both causation and harm were clearly implicit in the conclusion that compensation and output were actually suppressed by the challenged rules. A private plaintiff seeking damages would have to show causation and be able to quantify its harm, ${ }^{97}$ while a private plaintiff seeking an injunction would have to show "threatened loss or damage."98

95. FTC v. Actavis, Inc., 570 U.S. 136 (2013).

96. See 12 Phillip E. Areeda \& Herbert Hovenkamp, Antitrust Law Il 2046c (4th ed. 2020).

97. See Herbert Hovenkamp, Antitrust Harm and Causation, 99 Wash. U. L. Rev. 788, 836-51 (2021).

98. Id.; see 15 U.S.C.A. $\$ 26$ (1995) (causation requirement for private entitlement to antitrust injunction). 


\section{III. BALANCING AND THE “QUICK LOOK”}

One goal of the changes in the rule of reason in the time since Justice Brandeis has been to avoid, or at least limit, the need for "balancing"-a proposition with which the Alston district court agreed. ${ }^{99}$ The term balancing always sounds pleasing until someone actually has do to it. Further, it is important to remember that in economics most of the important values are cardinal-i.e., they need to have values attached to them before they are of very much use. This is not invariably true. For example, the Pareto principle is able to identify welfare improvements without balancing because the only time it measures welfare at all is when there is nothing to balance. Unanimity, for instance, is a useful indicator of a Paretooptimal condition. ${ }^{100}$

As soon as the prospect of both gains and losses is present, however, the issues become more complex. In the 1960s and 1970s Oliver Williamson in economics and Robert H. Bork in law developed a welfare tradeoff, or balancing, approach that netted out consumer losses from monopoly against productive efficiency gains. ${ }^{101}$ Bork then did antitrust an enormous disservice by naming this the "consumer welfare" principle even though one of its most potent effects is to approve of antitrust rules that harm consumers. The confusion has plagued antitrust to this day and almost certainly accounts for much of the opposition to the consumer welfare principle. By contrast, the true consumer welfare principle asks only if output is higher, or prices lower, as a result of a certain event; it

99. See In re Nat'l Collegiate Athletic Ass'n Athletic Grant-in-Aid Cap Antitrust Litig., 375 F. Supp. 3d 1058, 1104 (N.D. Cal. 2019), aff'd, 958 F.3d 1239 (9th Cir. 2020); see also id. at 1108 (quoting 7 Phillip E. Areeda \& Herbert Hovenkamp, Antitrust Law If 1507d (4th ed. 2017)):

A better way to view balancing is as a last resort when the defendant has offered a procompetitive explanation for a prima facie anticompetitive restraint, but no less restrictive alternative has been shown ... . The court must then determine whether the anticompetitive effects ... are sufficiently offset by the proffered defense.

The Supreme Court did not discuss balancing.

100. See Amartya Sen, Liberty, Unanimity and Rights, 43 Economica 217, 219-20 (1976); Kenneth Arrow, A Difficulty in the Concept of Social Welfare, 58 J. Pol. Econ. 328 (1950); see also Herbert Hovenkamp, Arrow's Theorem: Ordinalism and Republican Government, 75 Iowa L. Rev. 949, 950 (1990).

101. See Oliver E. Williamson, Economies as an Antitrust Defense: The Welfare Tradeoffs, 58 Am. Econ. Rev. 18 (1968); Robert H. Bork, The Antitrust Paradox: A Policy at War with Itself 106 (1978). 
does not try to balance the effects of reduced output against claimed offsetting efficiencies. ${ }^{102}$

As soon as an antitrust tribunal is required to balance in any situation that is not immediately obvious, it is out of its element. Competitive losses or harms would have to be quantified. That would require a court to identify all the costs of an exercise of market power and also to put a cardinal value on efficiencies. ${ }^{103} \mathrm{No}$ court can do these things except in the easiest cases.

Beginning with that premise, the three-stage rule of reason inquiry was designed in order to limit the circumstances when a court needs to engage in balancing. First, one looks at harms alone. They do not have to be quantified in any technical sense, but they must be determined to be substantial. Second, one looks at claimed benefits or other offsets. If there are none, then we have an easy caseall harms and nothing else. If benefits are proven, then we are in a more difficult situation because harms and benefits would have to be quantified. That is the paradigm that Oliver Williamson contemplated in his essay on welfare tradeoff models. ${ }^{104}$

Third, the less restrictive alternative is best viewed as a backstop-or another opportunity to make balancing unnecessary. If the defendants can achieve most of their objective through an available and effective less restrictive alternative, then the harm will be either eliminated or at least mitigated.

The Court found that the NCAA was quite correct in its argument that antitrust law does not require a firm to employ "anything like the least restrictive means of achieving legitimate business purposes." 105 Indeed, the use of least restrictive alternatives is much narrower than that. The query becomes relevant only after the first two steps of the rule of reason have been completed. The proffered alternative must be realistically available. ${ }^{106}$ Importantly, however, cardinal balancing can be completely avoided in the great majority of cases.

For example, suppose that a joint venture's aggregation of patents or other intellectual property rights has been shown to be un-

102. See Hovenkamp, Antitrust Harm and Causation, supra note 97.

103. See, for example, Williamson, supra note 101, which would have required courts to quantify the deadweight loss from created monopoly and then net this out against efficiency gains.

104. See id.

105. Nat'l Collegiate Athletic Ass'n v. Alston, 141 S. Ct. 2141, 2161 (2021).

106. Id. (“[A] 'skilled lawyer' will 'have little difficulty imagining possible less restrictive alternatives to most joint arrangements." " (quoting 11 PhiLlip E. AreedA \& Herbert Hovenkamp, Antitrust Law If 1913b, at 398 (2018))). 
reasonably exclusionary. The defendant is able to show that a particular acquisition or aggregation is valuable for innovation, but at that time the plaintiff might be able to show that a non-exclusive license could give the defendant everything it needs to improve its own technology, but not the right to exclude. Further, it is no answer that the non-exclusive right would be worth much less to the selling firm. The market determines that. In this case, an order compelling non-exclusivity would very likely address the competition problem fully. ${ }^{107}$

The more problematic issue respecting less restrictive alternatives was the district court's use of that idea to regulate the size of the compensation limit. Under the order, which the Supreme Court upheld, the NCAA could limit education-related benefits, ${ }^{108}$ "but only so long as those limits are no lower than the cash awards allowed for athletic achievement."109 This puts the court in a position uncomfortably close to that of a price regulator. For example, in a per se case in which defendants fixed the price of widgets at $\$ 10$ each, we would never say that fixing the price at $\$ 9$ is a less restrictive alternative. Of course, the per se rule would not permit such an approach. The price fix is unlawful no matter what its size.

If the price fix is subject to the rule of reason however-as it currently would be under the Supreme Court's holding that the rule of reason applies to all NCAA rules-then just such a possibility might arise. For example, suppose that the NCAA fixed the price of season tickets offered by individual teams-something that we would ordinarily expect to be covered by the per se rule. We would not want to get into the position of saying that pricing season tickets at $\$ 500$ is unlawful but a less restrictive alternative would be to price them at $\$ 400$. That would in fact turn the court into a price regulator.

In the one significant NCAA price-fixing case that did not involve compensation of amateur athletes, Law $v$. NCAA, the Tenth

107. Cf. Herbert Hovenkamp, Federal Antitrust Policy: The Law of ComPETITION AND Its PRActice $\$ 12.3$ (6th ed. 2020) (acquisition of nonexclusive right in order to render merger competitively harmless).

108. The district court listed these benefits as "academic achievement or graduation awards; summer school; fifth-or sixth-year aid; tutoring; academic support services; international student fees and taxes; professional program testing; and supplies." In re Nat'l Collegiate Athletic Ass'n Athletic Grant-in-Aid Cap Antitrust Litig., 375 F. Supp. 3d 1058, 1072-73 n.15 (N.D. Cal. 2019).

109. Alston, 141 S. C. at 2153. 
Circuit felt obligated to apply the rule of reason. ${ }^{110}$ It applied what it characterized as a "quick look" to an NCAA rule fixing the maximum salaries for secondary basketball coaches. In effect, the rule was deeply suspicious - all the way to the anticompetitive end of Justice Gorsuch's spectrum. ${ }^{111}$ The court then found that there were no offsetting procompetitive benefits. As a result, it held that it was unnecessary to pursue the issue of less restrictive alternatives. ${ }^{112}$

The Supreme Court in Alston also declined the NCAA's suggestion that the Court adopt a "quick look," which the NCAA had characterized as "abbreviated deferential review" to the compensation limitations. ${ }^{113}$ The principal argument by the NCAA was that "collaboration among its members is necessary if they are to offer consumers the benefit of intercollegiate athletic competition."114 The Court did agree that, if they apply at all, "quick look" approaches can work in both directions. ${ }^{115}$ In some cases, they can offer a quick path to condemnation, as the FTC requested in the California Dental $^{116}$ and Actavis ${ }^{117}$ cases, but they can offer a quick path to salvation, as the NCAA was seeking in Alston.

The Supreme Court has never been enthusiastic about the "quick look" doctrine, which calls for an intermediate query that falls between the per se rule and the rule of reason. Prior to Alston, it discussed the rule three times, but only to reject its use in the particular case before it. ${ }^{118}$ On the other hand, it has permitted forms of truncated analysis that fall somewhere short of the full rule of reason. ${ }^{119}$ While refusing to embrace a quick look, the Alston Court did observe that the Oklahoma Board of Regents case did sup-

110. Law v. Nat'l Collegiate Athletic Ass'n, 134 F.3d 1010, 1020 (10th Cir. 1998). While Justice Gorsuch came from the Tenth Circuit, he was not yet on it at the time.

111. See id.

112. Id. at 1024 n.16.

113. See Alston, 141 S. Ct. at 2155.

114. Id. (citing 13 Phillip Areeda \& Herbert Hovenkamp, Antitrust Law I 2100c (4th ed. 2020)).

115. Id.

116. Cal. Dental Ass'n v. FTC, 526 U.S. 756 (1999).

117. FTC v. Actavis, Inc., 570 U.S. 136 (2013).

118. Actavis, Inc., 570 U.S. at 159 (declining to apply "quick look"); Texaco, Inc. v. Dagher, 547 U.S. 1, 5-6 (2006) (observing, and not questioning, that the district court had refused to apply quick look doctrine); Cal. Dental Ass'n, 526 U.S. at 781 (declining to grant FTC's request for "quick look" analysis).

119. FTC v. Ind. Fed'n of Dentists, 476 U.S. 447 (1986) (truncated proof of anticompetitive effects); Actavis, Inc., 570 U.S. at 158-59 (truncated proof of both power and effects). 
port "abbreviated antitrust review." 120 That has always been the best way to think about the issue-not as three silos with per se, quick look, and full rule of reason as three discrete points along a line. Rather, methods of analysis lay along a "sliding scale" with varying amounts and kinds of evidence being necessary depending on the issues and the nature and availability of evidence. ${ }^{121}$ In Alston itself, application of the rule of reason was easy, mainly because the NCAA had conceded the central points-namely that the restraint had resulted in reduced compensation and reduced output. ${ }^{122}$

\section{IV. \\ LABOR SUPPRESSION: THE SEEN AND THE UNSEEN}

Alston is a forceful statement of one aspect of antitrust concern for labor. The Court spoke categorically of labor's interest in a competitive marketplace. In the process, it made clear that labor market competition is not in any sense derivative of competition on the other (output) side of the market. A cartel that suppresses wages is unlawful whether or not it also raises prices in product markets. ${ }^{123}$ This can be especially important when a firm or group of firms wield power in the labor market in which they purchase but are competitive in the output market where they sell their product.

Given that the issue in Alston was athlete compensation, the players and the teams existed in at least a quasi-employer-employee relationship. As a result, the decision is an example of the Supreme Court's relatively infrequent incursions into the relationship between labor and the antitrust laws. It was made all the more infrequent by the fact that there was no labor union. ${ }^{124}$

Nevertheless, the fact remains that this is only a small part of the antitrust interest in labor market competition. There is another very important sense in which the fortunes of labor are dependent on competition in product markets. Monopoly in product markets

120. Alston, 141 S. Ct. at 2157 (citing Nat'l Collegiate Athletic Ass'n v. Bd. of Regents of Univ. of Okla., 468 U.S. 85, 109 n.39 (1984)).

121. See Actavis, Inc., 570 U.S. at 159 (adopting a "sliding scale" approach (quoting Cal. Dental Ass'n, 526 U.S. at 780)); see also Hovenkamp, Rule of Reason, supra note 89 , at 122-23.

122. See discussion supra notes 26-27.

123. See discussion supra notes 28-31.

124. On antitrust and labor laws for unionized labor, see Brown v. Pro-Football, Inc., 518 U.S. 231, 249-50 (1996) (unionized football times); H.A. Artists $\mathcal{E}^{\circ}$ Assocs. v. Actors' Equity Ass'n, 451 U.S. 704, 707 (1981) (line between employees and independent contractors). Other decisions are discussed in 1B Phillip E. AreedA \& Herbert Hovenkamp, Antitrust Law II $255-57$ (5th ed. 2020). 
reduces output. Further, nearly all of labor, and particularly at lower salary levels, is a variable cost. As a result, reduced output in product markets leads directly and often proportionately to reduced demand for labor. The negative impact for labor of product market monopoly is very likely many times higher than the negative impact of labor market restraints. ${ }^{125}$

\section{A. “Amateurism" and Student Labor}

The Court also observed that the 1984 decision had included a lengthy discussion of "amateurism." Here, however, it found the concern to be relatively unimportant except perhaps for market definition-as a way of distinguishing the audience for collegiate athletics from that for professional athletics. ${ }^{126}$ Indeed, this suppression of amateurism as a fundamental concern may be one of the most enduring features of the Alston decision. The NCAA will no longer be able to justify a practice that suppresses student compensation simply by citing the preservation of amateurism.

The NCAA has a long tradition of promoting amateurism in collegiate athletics. Alston quoted this passage from the 1984 Oklahoma Board of Regents decision:

The NCAA plays a critical role in the maintenance of a revered tradition of amateurism in college sports. There can be no question but that it needs ample latitude to play that role, or that the preservation of the student-athlete in higher education adds richness and diversity to intercollegiate athletics and is entirely consistent with the goals of the Sherman Act. ${ }^{127}$

Notwithstanding that strong statement, in fact, the 1984 decision had relatively little to do with amateurism. At issue was nationwide commercial television contracts for the broadcast of NCAA football games. The NCAA had argued for a connection between the preservation of amateurism and limitations that served to equalize access to broadcasting to preserve competitive balance, but the Court disagreed. ${ }^{128}$ By contrast, Justice White's dissent in the 1984 case found a strong link between the NCAA's interest in preserving

125. See Hovenkamp, Worker Welfare and Antitrust, supra note 29; see also Edgar K. Browning, A Neglected Welfare Cost of Monopoly - and Most Other Product Market Distortions, 66 J. Pub. Econ. 127 (1997). One of the seminal studies was Leonard W. Weiss, Concentration and Labor Earnings, 56 Am. Econ. Rev. 96 (1966).

126. Amateurism is discussed further supra notes 101-10.

127. Nat'l Collegiate Athletic Ass'n v. Alston, 141 S. Ct. 2141, 2157 (2021) (quoting Nat'l Collegiate Athletic Ass'n v. Bd. of Regents of Univ. of Okla., 468 U.S. 85, 120 (1984)).

128. See Bd. of Regents of Univ. of Okla., 468 U.S. at 119. 
amateurism and the policy of limiting televised games. He argued that it served to spread revenue more evenly among participating schools, thus giving amateur athletes from schools with less successful athletic programs a fair chance. ${ }^{129}$

Subsequent lower court decisions did involve athlete compensation, however, and they made the role of amateurism more prominent. ${ }^{130}$ The Alston decision stands in contrast to that. Justice Kavanaugh's concurring opinion wrote as if concerns about amateurism were not that important. ${ }^{131}$ The majority did not go quite that far. Rather, the Court observed that the NCAA's own conception of amateurism had evolved very considerably since 1984, and that the NCAA had "dramatically increased the amounts and kind of benefits schools may provide to student-athletes."132 Most of these included things like larger scholarships or greater amounts of assistance to struggling students. ${ }^{133}$ Accompanying this, the amount of revenue produced by broadcasting of collegiate sports had increased many times-including a 70-fold increase in the price of broadcast rights for the annual March Madness NCAA basketball tournament. ${ }^{134}$ Further, "[w] hile the NCAA asks us to defer to its

129. Id. at 124, 135-36 (White, J., dissenting) (citations omitted):

[T] he [television restriction] plan fosters the goal of amateurism by spreading revenues among various schools and reducing the financial incentives toward professionalism. As the Court observes, the NCAA imposes a variety of restrictions perhaps better suited than the television plan for the preservation of amateurism. Although the NCAA does attempt vigorously to enforce these restrictions, the vast potential for abuse suggests that measures, like the television plan, designed to limit the rewards of professionalism are fully consistent with, and essential to the attainment of, the NCAA's objectives. In short, " $[t]$ he restraints upon Oklahoma and Georgia and other colleges and universities with excellent football programs insure that they confine those programs within the principles of amateurism so that intercollegiate athletics supplement, rather than inhibit, educational achievement." The collateral consequences of the spreading of regional and national appearances among a number of schools are many: the television plan, like the ban on compensating student-athletes, may well encourage students to choose their schools, at least in part, on the basis of educational quality by reducing the perceived economic element of the choice.

130. See, e.g., O'Bannon v. Nat'l Collegiate Athletic Ass'n, 802 F.3d 1059, 1063-66 (9th Cir. 2015); Law v. Nat'l Collegiate Athletic Ass'n, 134 F.3d 1010 (10th Cir. 1998); In re Nat'l Collegiate Athletic Ass'n I-A Walk-On Football Players Litig., 398 F. Supp. 2d 1144 (W.D. Wash. 2005); Adidas Am., Inc. v. Nat'l Collegiate Athletic Ass'n, 40 F. Supp. 2d 1275 (D. Kan. 1999).

131. Alston, 141 S. Ct. at 2167 (Kavanaugh, J., concurring).

132. Id. at 2158 (majority opinion).

133. Id.

134. See id. (observing that "[f]rom 1982 to 1984 , CBS paid $\$ 16$ million per year to televise the March Madness Division I men's basketball tournament. In 
conception of amateurism, the district court found that the NCAA had not adopted any consistent definition." 135 Rather, its definition had "shifted markedly over time." 136 The Court did not rule that concerns about preserving amateurism are irrelevant to the antitrust analysis, but clearly they are now less central.

The more important question for antitrust policy is whether and how these concerns about amateurism fit into Sherman Act analysis under the rule of reason. A strong concern to protect amateurism might effectively yield to the NCAA carte blanche to determine the appropriate compensation for its student athletes. The Court clearly rejected that. It also rejected the NCAA's own use of the term to defend a concept that had shifted over time and in fact had no clear definition. ${ }^{137}$ At the same time, however, the Court wrote a decision that was no broader than necessary to strike down rules in a way that permitted member schools to award limited compensation that certainly seems modest in comparison with professional salaries.

Absent intervention by Congress, this suggests either that the next shoe to drop will be any agreed-upon limitations whatsoever on student athlete compensation, or else a more stable and acceptable definition of amateur athletics and what kinds of limitations on competition that entails.

The antitrust laws are not an invitation to price regulation by another name. An agreement limiting student athletes to, say, $\$ 100,000$ would be just as unlawful under the Sherman Act as an agreement to deny them compensation altogether. These problems emerged in the Court's discussion of the lower court's decree, developed below. ${ }^{138}$

One approach would be for Congress to intervene, perhaps in the process defining the term "amateur" and proscribing reasonable limits on compensation and support. Another might be to permit the NCAA to produce a more defensible and stable idea of amateurism. Unfortunately, that train may already have left the station.

2016, those annual television rights brought in closer to $\$ 1.1$ billion." (citations omitted)).

135. Id. at 2163. 2019)).

136. Id. (citing the district court, 375 F. Supp. 3d 1058, 1070-74 (N.D. Cal.

137. Id. at 2163-64.

138. See infra notes 169-81. 


\section{B. Athlete Compensation and Competitive Balance}

The district court had rejected the NCAA's argument that limitations on athlete compensation were essential to achieving "competitive balance among teams." 139 The NCAA did not pursue the argument on appeal.

"Balance" can mean a number of things. The Supreme Court noted one particularly large imbalance, which was between student compensation and the multimillion-dollar salaries paid to some NCAA coaches, athletic directors, and the president of the NCAA. ${ }^{140}$

What the Court did not mention, however, was that the NCAA had attempted to cap the salaries of at least some coaches, but Justice Gorsuch's own previous court, the Tenth Circuit, had condemned the salary rules as antitrust violations in Law v. NCAA. ${ }^{141}$ As a result, member schools became liable for large treble damages awards. ${ }^{142}$ So the NCAA has been operating in a legal environment in which restraints on professional salaries were presumed to be unlawful. The result has been bidding wars among the top sports schools, with salary differentials on the order of as much as eightyto-one in various classifications of NCAA coaches. ${ }^{143}$

What happened to coaching salaries in the wake of Law may be a predictor of what will happen to student athlete salaries in a market in which all NCAA-imposed caps are removed. As a matter of perspective, however, only a small percentage of collegiate athletes go into professional leagues. For example, in 2020 there were 73,712 NCAA football participants, of whom 16,380 were deemed to be draft eligible. Of these, 254 were actually drafted. In basketball, 3,669 out of 16,509 were draft eligible but only 36 were

139. Alston, 141 S. Ct. at 2152.

140. See id. at 2151.

141. Law v. Nat'l Collegiate Athletic Ass'n, 134 F.3d 1010 (10th Cir. 1998).

142. After the decision, the parties settled for a damages award of $\$ 54,500,000$. See NCAA to Pay Coaches \$54.5M, CBS NEWS (Mar. 9, 1999, 6:32 PM), https://www.cbsnews.com/news/ncaa-to-pay-coaches-545m/ [https://perma.cc/ E9ZK-4EY5].

143. See Emily S. Sparvero \& Stacy Warner, The Price of Winning and the Impact on the NCAA Community, 6 J. Intercollegiate Sport 120, 127 (2013). For example, as of 2011, salaries of Division I coaches ranged from a low of $\$ 23,950$ to a high of $\$ 1,832,594$. Since then, a relatively small number of high paying NCAA coaches have earned salaries in the $\$ 5 \mathrm{~m}$ to $\$ 9 \mathrm{~m}$ range. In 2020, Nick Saban of the University of Alabama was at the top with a reported salary of $\$ 9.3$ million. See Scott Prather, 10 Highest Paid College Football Coaches in 2020, ESPN LAFAyetTe (Oct. 30, 2020), https://espn1420.com/10-highest-paid-college-football-coaches-in-2020/ [perma.cc/E9ZK-4EY5]. 
drafted. ${ }^{144}$ Of course, many others might go to minor or foreign leagues, although at significantly smaller salaries. But a very likely result will be that high offers will chase after a very small number of superstar athletes, very likely going to schools with strong athletic reputations in a particular sport.

In sum, it does not necessarily follow that the fixing of maximum student compensation in Alston presents exactly the same problem as the fixing of stadium hot dog prices. A stronger case can be made that student athlete compensation must be controlled in order to maintain competitive balance-a defense that is virtually universally rejected in the general run of cartel cases. But athletic conferences are owned by universities that have a broader educational mission. As a result, they may have an interest in maintaining broad participation in intercollegiate activities. ${ }^{145}$ For example, they regularly enforce such things as equalizing the number and size of scholarships that individual teams may offer. ${ }^{146}$ They select schools for particular "divisions" based on size and largely limit intercollegiate games to schools within a division, so that very large schools do not often play against very small ones. ${ }^{147}$ More generally, there is a well-supported belief that intercollegiate sports is best served by a situation in which teams of roughly equal ability and resources play one another. ${ }^{148}$ In the Name and Likeness licensing antitrust litigation, the district court denied summary judgment on the issue, although after expressing some doubts. ${ }^{149}$

In its 1984 decision, the Supreme Court agreed that the NCAA had a legitimate role in maintaining competitive balance within NCAA football, but it also held that this did not serve to justify the

144. See NCAA, Estimated Probability of Competing in Professional Athletics, NCAA (Apr. 8, 2020), https://www.ncaa.org/about/resources/research/estimatedprobability-competing-professional-athletics [https://perma.cc/B6G7-6KUC].

145. A wide literature has discussed the issue. See E. Woodrow Eckard, The NCAA Cartel and Competitive Balance in College Football, 13 REv. Indus. ORG. 347 (1998) (finding that competitive balance has not improved notwithstanding NCAA efforts); Steven Salaga \& Rodney Fort, Structural Change in Competitive Balance in Big-Time College Football, 50 Rev. Indus. Org. 27 (2017).

146. See Daniel Sutter \& Stephen Winkler, NCAA Scholarship Limits and Competitive Balance in College Football, 4 J. Sports Econ. 3 (2003).

147. See Brian M. Mills \& Steven Salaga, Historical Time Series Perspectives on Competitive Balance in NCAA Division I Basketball, 16 J. SpOrTs Econ. 614 (2015).

148. See Allen R. Sanderson \& John J. Siegfried, Thinking About Competitive Balance, 4 J. SpORTs Econ. 255, 256 (2003).

149. In re Nat'l Collegiate Athletic Ass'n Student-Athlete Name \& Likeness Licensing Litig., 37 F. Supp. 3d 1126, 1149-50 (N.D. Cal. 2014). 
challenged restraint on nationally televised games. ${ }^{150}$ In Alston, the Supreme Court paid very little attention to the issue, after noting that the district court had rejected it and observing that the NCAA did not appeal on that question. ${ }^{151}$ The district court in the closelyrelated O'Bannon case had also rejected an argument based on competitive balance after concluding that the NCAA presented insufficient evidence on the issue. ${ }^{152}$ In particular, that court cited the lack of adequate evidence that concerns about competitive balance affected desirability or audience size. ${ }^{153}$ Justice Kavanaugh also raised the issue briefly in his concurring opinion in Alston when discussing how the NCAA would operate in a regime in which all agreements governing athlete compensation were declared unlawful. ${ }^{154}$

Surprisingly, on this issue, professional sports appear to differ. In the American Needle case, the Supreme Court recognized concerns for maintaining competitive balance as "legitimate and important" in the development of professional (NFL) football. ${ }^{155}$ And in Major League Baseball v. Salvino, Inc., the Second Circuit found it to be an important interest to the preservation of professional baseball. ${ }^{156}$ In fact, the court in that case approved of a system in which revenues from the licensing of the intellectual property rights of the individual teams were pooled and distributed among them equally. ${ }^{157}$

One wonders why the concern about competitive balance should be regarded as legitimate for professional sports but not for collegiate sports. Intuitively, the opposite conclusion might seem more sensible. For the future, more extensive fact finding on this issue would be helpful, including more elaborate articulation by the NCAA.

150. Nat'l Collegiate Athletic Ass'n v. Bd. of Regents of Univ. of Okla., 468 U.S. 85, 117, 119-20 (1984).

151. Nat'l Collegiate Athletic Ass'n v. Alston, 141 S. Ct. 2141, 2153-54 (2021).

152. O’Bannon v. Nat'l Collegiate Athletic Ass'n, 7 F. Supp. 3d 955, 1001-02 (N.D. Cal. 2014).

153. Id. The Ninth Circuit affirmed the district court's ruling in part, reaching the same conclusion about competitive balance. O'Bannon v. Nat'l Collegiate Athletic Ass'n, 802 F.3d 1059 (9th Cir. 2015).

154. Alston, 141 S. Ct. at 2168 (Kavanaugh, J., concurring).

155. Am. Needle, Inc. v. Nat'l Football League, 560 U.S. 183, 204 (2010) (“' $[\mathrm{T}]$ he interest in maintaining a competitive balance' among 'athletic teams is legitimate and important.'” (quoting Nat'l Collegiate Athletic Ass'n v. Bd. of Regents of Univ. of Okla., 468 U.S. 85, 117 (1984))).

156. Major League Baseball Props., Inc. v. Salvino, Inc., 542 F.3d 290, 328-29 (2d Cir. 2008).

157. Id. at 334 . 
A related concern was balance as between professional and collegiate sports. More to the point, do we want NCAA athletics in the strongest schools to be nothing more than professional athletics by another name? The Alston Court did not disturb lower court findings that gave some credence to the argument that "professionallevel cash payments ... could blur the distinction between college sports and professional sports and thereby negatively affect consumer demand." 158 The lower court had observed:

[W] hen compared with having no limits on compensation, some of the challenged compensation rules may have an effect on preserving consumer demand for college sports as distinct from professional sports to the extent that they prevent unlimited cash payments unrelated to education such as those seen in professional sports leagues .... [H] owever, not all of the challenged rules in their current form are necessary to achieve this procompetitive effect, and there is a less restrictive alternative to the set of current challenged compensation restrictions. ${ }^{159}$

This close focus on consumer demand as the distinguishing feature dividing amateur and professional athletics seems far too narrow. The reason that collegiate athletics is distinctive is not simply because consumers view it that way, but also because colleges play an essential role in educational and personal development that professional teams do not. That issue, as noted below, has unfortunately been buried in a set of fundamentally jurisdictional concerns that involve the scope of "commerce." Once a court concludes that a particular restraint does not pertain to commerce, all debate over the antitrust merits of that restraint must end.

\section{$\mathrm{V}$. \\ "COMMERCIAL ENTERPRISE"}

The Sherman Act was passed under Congress' power to regulate commerce and applies only to commercial activities. ${ }^{160}$ This jurisdictional limitation has enabled the NCAA to show that at least some of its restraints are not commercial in nature and thus not governed by the Sherman Act. In addition, the NCAA is a nonprofit

158. Alston, 141 S. Ct. at 2153 (quoting the district court, 375 F. Supp. 3d 1058, 1104 (N.D. Cal. 2019)).

159. In re Nat'l Collegiate Athletic Ass'n Athletic Grant-in-Aid Cap Antitrust Litig., 375 F. Supp. 3d 1058, 1101 (N.D. Cal. 2019).

160. Sherman Antitrust Act of 1890, 15 U.S.C.A. $\S \S 1-2$. 
organization comprised mainly, although not entirely, ${ }^{161}$ of nonprofit educational institutions. Its principal job is not athletics but rather the education of students at an important transitional time in their lives. Most college athletes are 18 to 21 years old. In fact, the great majority of students who participate in NCAA athletics are not only amateurs at the time, but they will also never become professional athletes. ${ }^{162}$

For its part, the Sherman Act pays very little attention to the distinction between profit and non-profit institutions, although it pays a great deal of attention to the distinction between commercial and noncommercial activities. That is, whether the Sherman Act applies depends on the nature of the restraint, not of the entities who are engaged in it. This is not a consequence of any deep thought about the nature of educational institutions but rather that the jurisdictional reach of the antitrust laws extends only to "commerce."163

This distinction has actually served the educational community fairly well because the division between "commercial" and "noncommercial" permits universities to do a great many things that are an important part of educational policy, although probably not of antitrust policy, such as guaranteeing that student athletes obtain a good education and acting as partial substitutes for parents in a student's transitional period of life.

In Alston, the Court dismissed any claim that the NCAA and its member schools were not involved in a "commercial enterprise," but rather "oversee intercollegiate athletics "as an integral part of the undergraduate experience." 164 Commercial status seems unquestionable in this case, as it was in the Board of Regents case, ${ }^{165}$ which involved lucrative television contracts.

The statement should not be read to mean that the Court regarded every regulation that the NCAA might impose as a commercial one. Ordinarily the nature of the restraint, rather than of the

161. See Stephen L. Carter, What Is a For-Profit College, Anyway? And Who Decides?, BloomberG (Mar. 18, 2021, 11:30 AM), https://www.bloomberg.com/opinion/articles/2021-03-18/what-is-a-for-profit-college-anyway-and-who-decides [https://perma.cc/9HH4-73HM].

162. See discussion supra note 144.

163. See, e.g., United States v. Lopez, 514 U.S. 549, 561 (1995) (stating that mere possession of a firearm is not commerce, and thus not reachable under federal statute).

164. Nat'l Collegiate Athletic Ass'n v. Alston, 141 S. Ct. 2141, 2158 (2021) (quoting Brief for Petitioner at 31, Alston, 141 S. Ct. 2141 (No. 20-512)).

165. See Nat'l Collegiate Athletic Ass'n v. Bd. of Regents of Univ. of Okla., 468 U.S. 85 (1984). 
organization, determines its commercial character. ${ }^{166}$ As a result, nonprofit entities can be subjected to the antitrust laws, but their laws reach only "commercial" activities. ${ }^{167}$ To illustrate, suppose a student with low grades challenged the NCAA requirement that students must maintain a "C" average in order to participate in intercollegiate sports. ${ }^{168}$ Such a rule is literally output restricting, in the sense that some students otherwise able to play and perhaps even desirable for that purpose would be excluded. To that extent, it can even be said to "restrain trade." But the minimum GPA requirement is not a regulation of commerce, but rather of the school's academic enterprise. It is noteworthy that the NCAA and its teams very likely do not profit by limiting participation based on GPA. The same thing is true of NCAA disciplinary rules, which are "noncommercial" even though they can have a significant negative impact on a school's revenue. For example, the NCAA did not violate the antitrust laws by disciplining Penn State University for a set of incidents involving sexual abuse of collegiate athletes, at least some of whom were minors at the time. ${ }^{169}$ Finding that the NCAA's regulation of the conduct was not commercial entailed that the antitrust court lacked jurisdiction. ${ }^{170}$

On a related issue, the Court had no occasion to overrule baseball's long-standing judicially created immunity from the antitrust laws. ${ }^{171}$ That immunity was also based on Justice Holmes's conclusion in the early 1920 s that baseball was not "commerce." ${ }^{172}$ In $A l$ ston, the Court appeared not to think very much of the baseball

166. See 1B Phillip E. Areeda \& Herbert Hovenkamp, Antitrust Law II I 260-62 (5th ed. 2020).

167. See, e.g., Missouri v. Nat'l Org. for Women (NOW), 620 F.2d 1301, 1302 (8th Cir. 1980) (political boycott against states that did not ratify the Equal Rights Amendment not reachable under Sherman Act).

168. See Agnew v. Nat'l Collegiate Athletic Ass'n, No. 1:11-GV-0293, 2011 WL 3878200 , at $* 8$ (S.D. Ind. Sep. 1, 2011) (noting NCAA's minimum GPA requirement).

169. Pennsylvania v. Nat'l Collegiate Athletic Ass'n, 948 F. Supp. 2d 416 (M.D. Pa. 2013).

170. Id. at 422:

To establish its Section 1 antitrust claim under the Sherman Act, Plaintiff cannot allege just any harm, but must point to harm directed at commercial activity of the type the Sherman Act is designed to address. Further, Plaintiff must establish that Defendant's action affected the kind of antitrust activity over which this Court has jurisdiction.

171. See Fed. Baseball Club of Baltimore, Inc. v. Nat'l League of Pro. Baseball Clubs, 259 U.S. 200 (1922); 1B Phillip E. Areeda \& Herbert Hovenkamp, AntiTRUST LAw If 251(h) (2) (5th ed. 2020).

172. Fed. Baseball Club of Baltimore, 259 U.S. at 208-09 ("[E]xhibitions of base ball" are not "trade or commerce in the commonly accepted use of those 
exemption, but it noted that the route to overruling it was through Congress, and the same thing should apply to the present decisions concerning athlete compensation. ${ }^{173}$ It noted that Congress had created antitrust immunities in the past, ${ }^{174}$ "[b]ut until Congress says otherwise, the only law it has asked us to enforce is the Sherman Act, and that law is predicated on one assumption alone 'competition is the best method of allocating resources' in the Nation's economy." 175

VI.

THE ALSTON DECREE

\section{A. Scope}

The Alston Court was also concerned about administrability of the lower court's decree, ${ }^{176}$ and the NCAA proffered some objections. In this case, however, the Court saw the proper approach as keeping the decree open to continual modification rather than rejecting its use. The Court acknowledged that "static judicial decrees in ever-evolving markets may themselves facilitate collusion or frustrate entry and competition." 177 As a result, "[j] udges must be open to reconsideration and modification of decrees in light of changing market realities" because conditions may vary over time. ${ }^{178}$ Further:

"An antitrust court is unlikely to be an effective day-to-day enforcer" of a detailed decree, able to keep pace with changing market dynamics alongside a busy docket. Nor should any court "impose a duty ... that it cannot explain or adequately and reasonably supervise." In short, judges make for poor "central planners" and should never aspire to the role. ${ }^{179}$

The Court more-or-less dismissed concerns raising the possibility that the NCAA would act in bad faith. For example, the district court's injunction permitting some post-eligibility internships could

words .... [P] ersonal effort, not related to production, is not a subject of commerce.”).

173. Nat'l Collegiate Athletic Ass'n v. Alston, 141 S. Ct. 2141, 2160 (2021).

174. Id. at 2159 (giving examples).

175. Id. at 2160 (quoting Nat'l Soc'y of Pro. Engineers v. United States, 435 U.S. 679,695 (1978)).

176. Id. at 2163 ("Judges must be wary . . . of the temptation to specify "the proper price, quantity, and other terms of dealing'-cognizant that they are neither economic nor industry experts." (quoting Verizon Commc'ns, Inc. v. Law Offs. of Curtis V. Trinko, LLP (Trinko), 540 U.S. 398, 408 (2004))).

177. Id. at 2161 (citing Trinko, 540 U.S. at 414).

178. Id. at 2163 (citing Cal. Dental Ass'n v. FTC, 526 U.S. 756, 781 (1999)).

179. Id. (quoting Trinko, 540 U.S. at 415, 408). 
be circumvented by the use of different terminology. It might permit a school to grant "a sneaker company or auto dealership" with "extravagant salaries" as a post-eligibility "internship."180 In any event the NCAA, subsequent to the district court's opinion, had adopted new regulations that only a "conference or institution" may fund post-eligibility internships. ${ }^{181}$ Further, the NCAA retained the ability to define appropriate educational benefits, thus "leaving . . . room to police phony internships." 182 It concluded that "the NCAA may seek whatever limits on paid internships it thinks appropriate." 183

The NCAA also attacked a part of the decree permitting schools to limit academic or graduation achievement awards, provided that those limits were "no lower than its aggregate limit on parallel athletic awards," which were at the time " $\$ 5,980$ per year." 184 The Court also noted that under the decree, "the NCAA is free to forbid in-kind benefits unrelated to a student's actual education; nothing stops it from enforcing a "no Lamborghini' rule."185

\section{B. Antitrust Regulatory Decrees: Uses and Limitations}

The Court observed that even a complex decree such as this one could be subject to clarification and, if necessary, modification. Further, the NCAA "remains free" to seek such guidance, but it has done so only once. ${ }^{186}$

The Court also noted that the district court gave the NCAA "considerable leeway" even with respect to education-related benefits:

[T] he court provided that the NCAA could develop its own definition of benefits that relate to education and seek modification of the court's injunction to reflect that definition. The court explained that the NCAA and its members could agree on rules regulating how conferences and schools go about providing these education-related benefits. The court said that the NCAA and its members could continue fixing education-related cash awards, too-so long as those "limits are never lower than the limit" on awards for athletic performance. And the

180. Id. at 2164 (quoting Brief for Petitioner at 37-38, Alston, 141 S. Ct. 2141 (No. 20-512)).

181. Id. (citation omitted).

182. Id.

183. Id. at 2165 .

184. Id.

185. Id.

186. Id. at 2165-66. 
court emphasized that its injunction applies only to the NCAA and multiconference agreements; individual conferences remain free to reimpose every single enjoined restraint tomorrow-or more restrictive ones still. ${ }^{187}$

The very last sentence of the quoted statement is peculiar because the individual conferences within the NCAA also operate as agreements among the participating teams. It is unclear why, if a restraint covering the entire NCAA is unlawful, a restraint covering only the Big Ten or Pac-12 conference would be permissible, but the Court did not elaborate.

The Court rejected a variety of objections to the decree. Nevertheless, it bears observing that all of the challenges were from the NCAA, arguing that the decree limited the NCAA's control excessively. The Court clarified that its focus was "only on the objections the NCAA [ ] raised."188 It "express[ed] no views" on other issues. ${ }^{189}$ The Court did not categorically approve the restrictions on other compensation that might sometime be challenged by the players as too expansive. It then closed with:

Some will think the district court did not go far enough. By permitting colleges and universities to offer enhanced education-related benefits, its decision may encourage scholastic achievement and allow student-athletes a measure of compensation more consistent with the value they bring to their schools. Still, some will see this as a poor substitute for fuller relief. At the same time, others will think the district court went too far by undervaluing the social benefits associated with amateur athletics. For our part, though, we can only agree with the Ninth Circuit: "The national debate about amateurism in college sports is important. But our task as appellate judges is not to resolve it. Nor could we. Our task is simply to review the district court judgment through the appropriate lens of antitrust law." That review persuades us the district court acted within the law's bounds. ${ }^{190}$

In the context of the complex and enduring antitrust issues that relate to the NCAA's governance of collegiate athletics, there may be no alternative to a decree such as this one. The Court's largely enthusiastic approval should not be read, however, as a categorical endorsement of ongoing regulatory decrees in other anti-

187. Id. at 2164 (citations omitted).

188. Id. at 2155 .

189. Id. 2020)).

190. Id. at 2166 (quoting the Ninth Circuit, 958 F.3d 1239, 1265 (9th Cir. 
trust areas. Whether it does so remains to be seen. But as a starting premise, the line between antitrust and regulation involves the persistently difficult question of when markets can govern themselves and when they require ongoing governmental supervision. One shudders to think, for example, of a regime that left competitively threatening mergers in place subject to ongoing judicial supervision by regulatory decree. As a result, the impulse is strong that a merger decree must restore the market to a position where it can operate competitively without ongoing administration. ${ }^{191}$ One problem is that structural relief in a case such as NCAA is neither desirable nor practical. In any event, no one was asking for it.

VII.

\section{JUSTICE KAVANAUGH AND UNRESOLVED ISSUES}

Justice Kavanaugh alone concurred. The principal point of his concurring opinion was to suggest that the NCAA's remaining but unappealed compensation rules might be unlawful under the Sherman Act as well, effectively leaving the compensation issue to the market. ${ }^{192}$ Given the length that the Court's opinion went to emphasize what the district court did not do, this decision reads a little more like a partial dissent rather than a concurrence. Under the Court's characterization, he observed, comments about amateurism should be regarded as "stray" and not to be accorded much weight. Indeed, he described them as "dicta" that "have no bearing on whether the NCAA's current compensation rules are lawful." ${ }^{193}$ Further, he believed that all the compensation limitations imposed by the NCAA should be subject to ordinary rule of reason analysis, and the Court had made clear that the NCAA is not entitled to an antitrust exemption. ${ }^{194}$

From that point, Justice Kavanaugh found "serious questions whether the NCAA's remaining compensation rules can pass muster under ordinary rule of reason scrutiny." 195 As he observed, "[t] he NCAA's business model would be flatly illegal in almost any other industry in America."196

191. On antitrust regulatory decrees in mergers, see 4A Phillip E. AREedA \& Herbert Hovenkamp, Antitrust Law II 990c (4th ed. 2016).

192. Alston, 141 S. Ct. at 2166-67 (Kavanaugh, J., concurring).

193. Id. at 2167.

194. Id.

195. Id.

196. Id. 
Justice Kavanaugh also acknowledged the possibility of legislation as an alternative to antitrust litigation. ${ }^{197}$ Another possibility is collective bargaining which would presumably subject NCAA athlete employment issues to the labor immunity, which limits the application of the antitrust laws to much of professional sports. ${ }^{198}$ Somewhat mysteriously, he also suggested "some other negotiated agreement." 199 In general, however, an agreement that violated the Sherman Act would not be enforceable. He did end, however, with this supplication on behalf of the athletes:

Nowhere else in America can businesses get away with agreeing not to pay their workers a fair market rate on the theory that their product is defined by not paying their workers a fair market rate. And under ordinary principles of antitrust law, it is not evident why college sports should be any different. The NCAA is not above the law. 200

VIII.

\section{CONCLUSION}

The Alston decision did not address every question about student athlete compensation. The Supreme Court also made clear that it was addressing only the NCAA's, not the students', objections to the district court's decree. One can anticipate future challenges from students claiming, as Justice Kavanaugh suggested, that all agreed-upon restrictions on student athlete compensation are unlawful. But they will do so in the face of a unanimous decision that was sympathetic to the district court's decree overall. Even the Supreme Court's dicta will be taken seriously.

That does not necessarily mean that Congressional intervention is unlikely or ill-advised. There is also good precedent for it. For many years, medical schools have run a "resident matching" program for recent graduates that assigns them by lottery to a particular employer for a residency. That practice would almost certainly constitute market division, per se unlawful under the Sherman Act. After a district court held just that, Congress passed legislation that immunized the practice from the antitrust laws. ${ }^{201}$ If Congressional action occurs in the NCAA situation, however, it is

197. Id. at 2168.

198. See 1B Phillip E. Areeda \& Herbert Hovenkamp, Antitrust Law If II 255-57 (5th ed. 2020).

199. Alston, 141 S. Ct. at 2168 (Kavanaugh, J., concurring).

200. Id. at 2169.

201. Confirmation of Antitrust Status of Graduate Medical Resident Matching Programs, 15 U.S.C.A. § 37b; see Jung v. Ass'n of Am. Med. Colls., 339 F. Supp. 2d 
very likely that more than student compensation will be on the table. ${ }^{202}$

The one fundamental thing that the Court did not seriously address, however, is the one that concerns antitrust policy rather than the complex role played by the NCAA in both education and athletics. Has the Court made it any easier for the next private rule of reason plaintiff to win a case, particularly where the challenged practice is more ambiguous than the nearly naked cartel that the Alston case involved?

\footnotetext{
26, 34 (D.D.C. 2004), aff'd, 184 Fed. Appx. 9 (D.C. Cir. 2006), cert. denied, 549 U.S. 1156 (2007).

202. For example, Congress has already entertained proposals to limit the salaries of highly paid college coaches. See Dennis Dodd, Proposed Federal Law Seeks to Limit Skyrocketing Salaries of College Coaches, CBS SporTs (Jan. 28, 2020, 2:22 PM), https:/ / www.cbssports.com/college-football/news/proposed-federal-law-seeks-tolimit-skyrocketing-salaries-of-college-coaches/ [https://perma.cc/S5MJ-5HF3].
} 
